\begin{tabular}{|l|l|l||}
\hline \multicolumn{2}{|c|}{ PublisherInfo } \\
\hline \hline PublisherName & $:$ & BioMed Central \\
\hline \hline PublisherLocation & $:$ & London \\
\hline \hline PublisherImprintName & $:$ & BioMed Central \\
\hline \hline
\end{tabular}

\title{
SCID mouse model of inflamed RA synovium
}

\begin{tabular}{|c|c|c|}
\hline \multicolumn{3}{|c|}{ ArticleInfo } \\
\hline ArticleID & : & 268 \\
\hline ArticleDOI & : & 10.1186/ar-2002-76700 \\
\hline ArticleCitationID & : & 76700 \\
\hline ArticleSequenceNumber & : & 21 \\
\hline ArticleCategory & : & Paper Report \\
\hline ArticleFirstPage & : & 1 \\
\hline ArticleLastPage & : & 4 \\
\hline ArticleHistory & : & $\begin{array}{ll}\text { RegistrationDate } & : 2002-3-28 \\
\text { Received } & : 2002-3-28 \\
\text { OnlineDate } & : 2002-3-28\end{array}$ \\
\hline ArticleCopyright & : & Biomed Central Ltd2002 \\
\hline ArticleGrants & : & \\
\hline ArticleContext & : & 130754411 \\
\hline
\end{tabular}


Willemijn van der Laan, ${ }^{\text {Aff1 }}$

Affl Dept of Rheumatology and Clinical Immunology, Academic Medical

Center, Amsterdam, The Netherlands

\section{Keywords}

rheumatoid arthritis, SCID model, synovitis

\section{Context}

Synovitis in rheumatoid arthritis (RA) involves local activation of lymphocytes, infiltration of inflamatory cells, synovial hyperplasia and angiogenesis. The current animal and in vivo models for RA have their limitations, since they do not reproduce all of the clinical and histopathological features of RA. The aim of the present study was to examine whether synovial tissue taken from RA joints retains its phenotypic and functional features after engraftment in a severe combined immunideficient (SCID) mouse, in order to develop an experimental model that reflects human RA without losing the complexity of RA synovitis.

\section{Significant findings}

Synovial tissue was taken from RA patients and either directly snap-frozen or implanted under the skin of SCID mice for 3, 6, or 12 weeks and snap-frozen thereafter for immunohistochemical or molecular analysis. For some experiments, CFSE-labelled enriched T cells were injected in the tail veins.

Similar numbers and types of leukocytes, including lymphocytes, persisted until 12 weeks after engraftment. The grafts underwent reorganisation such that $\mathrm{CD} 68^{+}$myeloid lineage cells were scattered throughout the graft, the lining layer was no longer demarcated and the fibroblasts became denser. Injected $\mathrm{T}$ cells migrated and accumulated specifically into the grafts. Human endothelial cells remained activated and markers of angiogenesis were still detectable after 12 weeks of engraftment. B cell and monocyte activity persisted until 60 days.

The authors concluded that the SCID mouse model of RA maintains many of the phenotypic and functional features of the inflamed RA synovium and that this model provides a unique model to examine the interaction of the RA microenvironment with the major components of the inflammatory process. 


\section{Comments}

The value of this model is that it consists of human RA synovial tissue that largely maintains its features after engraftment. It overcomes the limitations of other animal models, in which the induced arthritis is distinct from human RA, as well as overcoming limitations of in vitro models or the SCID mouse coimplantation model that study the behaviour of isolated cells and therefore lack the complexity of RA synovitis. Furthermore, because of its simplicity, the proposed model is easy to use and to reproduce. The use of engraftments of RA synovial tissue in SCID mice as a model for RA was first established in the early 1990s. Some findings are reproduced, but in contrast to the lymphodepletion in the grafts reported by others (a loss of one of the RA synovial features), the maintenance of lymphocytes was observed here. The authors suggest that lymphodepletion occurs when synovial pieces are too small; the size of the pieces used in this model were $0.1-0.2 \mathrm{~cm}^{3}$. Another interesting and novel finding is the persistence of active angiogenesis in the grafts. These findings can be used to improve existing SCID-RA models such as the synovium-cartilage coimplantation model described (see Additional information).

A limitation of this model is that it lacks environmental influences from outside the synovium and the reorganisation of myeloid lineage cells and fibroblasts may be a result of this. Furthermore, this model is not suitable to study pathogenetic mechanisms in the very early phase of RA as synovectomy is only usually performed in cases of established synovitis. Nevertheless, this model makes it possible to study the interaction of different cell types within the RA synovium and to study effects of experimental therapeutic strategies.

\section{Methods}

SCID mice, RA synovial tissue engraftment, Histology and immunohistochemistry, ELISA's for human Ig and IL-6, RT-PCR, cDNA PCR

\section{Additional information}

Geiler T, Kriegsmann J, Keyszer GM, Gay RE, Gay S: A new model for rheumatoid arthritis generated by engraftment of rheumatoid synovial tissue and normal human cartilage into SCID mice. Arthritis Rheum 1994, 37:1664-1671. 


\section{References}

1. Davis LS, Sackler M, Brezinschek RI, Lightfoot E, Bailey JL, Oppenheimer-Marks N, Lipsky PE: Inflammation, immune reactivity, and angiogenesis in a severe combined immunodeficiency model of rheumatoid arthritis. Am J Pathol. 2002, 160: 357-367.

This PDF file was created after publication. 